\title{
ISSUES AND CHALLENGES IN MAINTAINING MOTIVATION TO LEARN ENGLISH IN RURAL MADRASAH CONTEXT
}

\author{
Mochammad Imam Machfudi \\ Email:imam.machfudi@gmail.com
}

State Institute of Islamic Studies (IAIN) Jember

\begin{abstract}
Issues and challenges in teaching English in rural madrasahs are enormous. Despite the fact that English is considered to be a difficult subject, its presence as a compulsory subject does not seem desirable in such a situation. In this socio-cultural context, maintaining motivation is an important element among the challenges where the students are not motivated to learn English. This article explains the issues and challenges and the motivational strategies developed by Madrasah Tsanawiyah teachers of English in teaching English in their context and the impact on their students. By analysing the teachers' lived-experience through their stories this research finding shows that there are three kinds of motivational strategies enacted by the teachers of English in the rural areas of East Java including giving rewards, positive feedback, and increasing self-esteem and self-confidence. These three elements of external motivation indicate that the motivation plays a significant role in engaging students to learn English.
\end{abstract}

Keywords: motivational strategies, rural madrasahs, English language teaching

\section{INTRODUCTION}

Motivation plays a pivotal role in English language teaching and learning without which teaching and learning second (foreign) language could not result at maximum outcome. In maintaining motivational strategies, the teachers of English in rural areas faced a number of challenges in increasing students' motivation in learning English. The teachers already knew that the motivated students seemed in the classroom to be the enthusiastic ones to receive the lessons. However, those who were not motivated appeared lethargic to be involved in the classroom activities. The major challenge was the diverse situation and 
condition of the students in madrasah and that there was limited number of self-motivated students.

This article is based on my research in three districts in East Java including Bondowoso, Probolinggo and Pamekasan in Madura Island to investigate the issues and challenges faced by the teachers of English in maintaining motivational strategies. Eight Madrasah Tsanawiyahteachers of English were observed and interviewed. The classroom observations wereconducted as the instrument that enabled me to portraythe teachers' classroom pedagogic practices(Bogdan\& Biklen, 2007; Creswell, 2012; Denzin \& Lincoln, 2011). The narrative approach was engaged to understand teachers' lived-experience in teaching English in their context (Bauer \& Gaskell, 2006; Chase, 2005; Clandinin \& Connelly, 2000).

My observation indicated that despite the position of English as a foreign language, diverse situations and conditions in most of rural areas, there were a limited number of intrinsically motivated students and this has been identified as a major challenge. The research findings showed that teachers had engaged different motivational strategies which impacted the students to learn English that will be elaborated in the following observation and interview results.

\section{EXTRINSIC MOTIVATION}

This study indicated a range of different strategies mostly used by the teachers. A teacher perceived that each level of student learned differently and thus the strategy used would be different, "I think with different ages students learn differently" (interview with Bu Melisa). The observations were conducted in three rural madrasahs in the district of Bondowoso, three madrasahs in the district of Probolinggo, and two madrasahs in the district of Pamekasan. From the observations of the eight classroom practices, further results of motivational strategies employed by teachers are outlined as follows:

\section{GIVING REWARDS}

The data taken from the observation showed that one of the strategies used by teachers to motivate students was to give students rewards for achieving or finishing a task well. During the observation 
in MTs Nurul Huda in the district of Probolinggo, I witnessed that students who received souvenirs from Pak Ahmad were delighted. While giving the presents he praised by showing two thumbs up and said "good job". It was evident that this strategy had raised students' enthusiasm in following the English lesson. In the lesson, Pak Ahmad had successfully contextualised his practice in which he was able to link his real situation into classroom practice. The story of his trip to Yogjakarta and the means of transportation he used had linked up with the topic of the lesson that day. He intentionally brought souvenirs he had bought in Yogjakarta to be given to the students in order to motivate them. The gift from Pak Ahmad had positively triggered the other students to do the tasks better.

\section{POSITIVE FEEDBACK}

The data taken from the observations indicated that giving positive feedback was useful in increasing students' motivation in learning English. My observation in Bu Maria's class indicated that students were even more enthusiastic after receiving praise from the teacher. Bu Maria looked very generous in praising students' efforts; for example, when a student responded her question correctly she commented "well done, great job". This positive feedback has made her students' eyes glitter. I witnessed this symptom of happiness was resulted from the positive feedback.

Similarly, in the classroom observations that were conducted in all the eight different schools, the teachers showed quite alike tendency to uplift students' enthusiasm in learning English. This situation was extremely different compared to nine or ten years ago said a teacher. I identified words frequently used by teachers in their classroom practices like "good, very good, excellent, nice job, wonderful," ended up in student motivation in learning. It was pivotal to pay attention to the influence of positive feedback toward learners' achievement in learning English. This investigation showed that positive feedback had greater influence in increasing learners' motivation to learn English. Notwithstanding the achievement of their learning, learners need to be boosted to a certain level of confidence to provide them enough room to grow their intrinsic motivation to learn English better. 
The interview results showed that various strategies have been applied in increasing student motivation. One of the motivational strategies engaged by the teachers under study is to encourage students to speak English or to involve them in a fun and authentic activities in group discussion or pair work to increase their confidence.

The following story was taken from the district of Bondowoso. Apart from teaching in Madrasah Tsanawiyah (MTs) Bu Melisa has also been teaching in Senior High School (SMA) in the same Yayasan (foundation). When she taught at SMA many of her students in MTs were going to the SMA. Her former MTs students are now in year 10 in the SMA where she has been teaching. They were asking her to provide stickers as rewards for those who can finish a task well. But she wisely said that they were already grown up and did not need stickers. When teaching in MTs she usually encouraged the students to learn English by giving them stickers for those who were the best in doing the task including the most active student, the most disciplined student, or other best categories they decided together with the teacher. In year 10 of the SMA they were eager to be treated as if they were still MTs students. Below is the interview script with Bu Melisa:

I: It's very challenging teaching in two schools. Can you give a story about that?

Melisa: In SMA and in the MTs, usually my students from MTs continue their study in senior high school in our same er...yayasan, foundation, in the same foundation. So my students in MTs again being my student in SMA [giggling]

I: You use the same materials, same techniques?

Melisa: No. I'm using other technique because in senior high school I face the different problem. In senior high school the curriculum is more like I said before is more to $75 \%$ is for reading and writing. Not as fun as MTs and it's very full of topic they have to learn. Very very full subject.Er...so er..in the grade ten after they graduate from MTs so they move to senior high school in grade ten, my students ask me: "ustadzah, don't you give us a sticker like before, like in MTs?" No, no I don't have sticker for senior high school. Then when I came home I just realised that maybe student even in senior high school they still need a fun and authentic learning in their class and build their confidence in learning as well(Interview: TB3_mot) 
The interview result showed that motivating students in learning English in such situation is challenging. The teachers have attempted various strategies in order that English becomes an interesting subject. A number of motivational strategies have been employed by the teachers in increasing students' learning. The teacher was aware that students need to be motivated in every school level. In $\mathrm{Bu}$ Melisa case, her senior high students wanted her to give rewards. But she knew that different level will learn differently. Yet they need external motivation and engagement from the teacher. Interestingly $\mathrm{Bu}$ Melisa focused on building students' confidence in learning.

The interview result from the district of Probolinggo showed that Pak Ahmad's students were shy students. He motivated them by saying that they were the same condition. He ensured they could establish learning because all in the classroom were not using English in the communication. They have to use English in the classroom in order to develop their English. One of the motivation strategies he used was giving the students praise for example by using "two thumbs up" and said "good job" to students who demonstrated good effort. Pak Ahmad found it effective to raise students' enthusiasm as well. He explained that:

Most of them are shy students. I said that they are same with me, for example, and we have same chance to establish our English. In the next day they look have enthusiastic in learning. I always praise my students er...by giving two thumbs or say good job... and they look happy (Interview: TP3_mot).

\section{BUILDING SELF-ESTEEM AND SELF-CONFIDENCE}

From the observation, the students in the rural area in this research showed overall low self-esteem. They felt that they were left behind being lived in rural area, under-developed, and economically poor students. They were not confident being far from cities which provide all sort of facilities, information, and established environment.

The data taken from observation showed that the teachers in those three districts wanted the students to believe in their own attainment. In the classrooms, the compliment such as "Yes, you can, don't worry" was proved effective to trigger students to be brave in expressing their ideas. 
The data from the observations and interviews indicated that there was a challenge similar to building self-esteem, a teacher should be able to raise students' awareness in order to motivate the unmotivated student in learning English. One of the strategies employed by the rural teacher has been telling them that "English is now international language." My interview showed that this strategy was mostly used by teachers, for example, by Bu Maria, Bu Melisa, and Pak Ahmad used this phrase to motivate their students. The other strategy used was by saying, "You will get a good job if you can speak English" (Interview: TP3_mot). The other interview result from the district of Pamekasan, the teacher (Bu Nadirah) used sentence such as "You can be a good English teacher and go to overseas" to motivate students particularly to build their self-esteem and confidence (Interview: TPam1_mot).

\section{FINDINGS ON STRATEGIES IN MOTIVATING STUDENTS}

From observation and interview results the research showed that:

1. In some schools, students demonstrated low motivation in learning English

2. The teachers showed the ability to employ motivational strategies such as giving reward, giving positive feedback, and maintaining students' learning confidence

3. The teachers were aware that different level of students learn differently and motivational strategies engaged were also different

4. The teachers told the students that they are similar in socio-cultural condition being foreign language learners that need to increase their awareness to improve their English

5. The teachers employ various motivational strategies to build selfesteem and self-confidence including motivating the unmotivated

\section{DISCUSSION}

The success of language learning has been credited according to students' levels of motivation (Renandya, 2014). During the process of teaching and learning in the classroom, motivation plays a pivotal role in increasing students' enthusiasm, commitment, and involvement 
(Dornyei, 2001a). Furthermore, Dornyei pointed out that "in the vast majority of cases learners with sufficient motivation can achieve a working knowledge of a Second Language (L2), regardless of their language aptitude or other characteristics. Without sufficient motivation, even the brightest learners are unlikely to persist long enough to attain any really useful language"(p.5). Therefore, students should maintain their motivation in the classroom activities, because their enthusiasm will impact on their achievement in learning.

In the recent studies on motivation, Unshod $(2010,2011)$ has more specifically concerned with the relationship between motivation and autonomy.In many cases, the motivated students are those who are autonomous learners. The research finding shows that the motivation to learn English came from outside of the students. Therefore, it is important that the teachers need to help students maintain their internal motivation by, e.g. utilising a contextual and collaborative approach, so that the learning process in the classrooms becomes more fun, challenging, and motivating as well (Machfudi, 2013). The learning process will give enough room for learners' initiation, creativity, and autonomy. As such, maintaining motivation relates to how teachers improve students' awareness to be autonomous learners.

In the teaching and learning process, a teacher is challenged to always build students' self-esteem, by building good rapport in order to a create non-threatening atmosphere. The teacher is also advised to give positive feedback by giving praise and meaningful suggestion, and never demotivate students. Roberts (2012) pointed out that selfesteem refers to a condition of how individuals feel about themselves. It is a positive regard toward oneself. It develops from experiences and situations that shape how someone views her/himself. Further she said that when someone love her/himself, their self-esteem improves, which make them more confident. In other words, when confidence is increasing and thus someone will potentially work on well in any areas of lives.

Another issue in mainstream motivational psychology has been the self-determination theory proposed by Deci and Ryan (1985). This theory included the well-known distinction between intrinsic and extrinsic motivation. Deci and Ryan distinguished motivation based on 
the different reasons or goals that give rise to an action. "Intrinsic motivation refers to doing something because it is inherently interesting or enjoyable, while extrinsic motivation refers to doing something because it leads to separable outcome" (Ryan \& Deci, 2000, p. 55). In the classroom practices showed in the research finding, students should be aware that they need to change the motivation from outside into a "build-in" motivation mediated by their teachers. And thus, the teachers can gradually focus on building students' internal motivation by, for instance, making the learning of English in classrooms a need. It can be fun activities. If learning is an enjoyable activity, then the students will automatically build their internal motivation.

\section{Motivational Strategies}

It has been widely discussed by motivational theorists that motivation plays a very important role in second language learning (e.g. Deci \& Ryan, 1985; Dornyei, 2001a, 2001b; Gardner \& Lambert, 1959; Renandya, 2014; Ushioda, 2010, 2011). The term motivational strategies relates to how teachers demonstrate techniques in promoting and maintaining students' motivation. Motivational strategies promote individual's learning behaviour and since every individual learns differently, there are diverse ways of promoting motivation (Dornyei, 2001a, 2014) . Renandya (2014) suggested the effective strategies such as how the teachers motivate students, how the teachers use the strategies, how the text used, how the tasks given, or how the tests administered by the teachers for motivating L2 learners because motivated learners are more enthusiastic, goaloriented, committed, persistent and confident in learning.

Motivational strategies engaged by the teachers in the rural madrasahs under study were giving positive feedback, rewards, and building students' self-confidence thereby increasing self-awareness and opportunities for improvement in student learning. Positive feedback increases students' motivation to learn English. The observable classroom attitude indicated that the teachers' involvement increased students' motivation (Ryan \& Deci, 2000) to follow the lessons. When the students understood the value of learning, they 
appeared motivated. By boosting students' learning step by step, the teachers increased students' enthusiasm leading to self-motivated learning. As such, paying attention to the influence of positive feedback toward learners' attainment in learning English is essential. This study also suggests that each learner learns differently, thus the strategies to motivate the students ought to be different depending on the context, the learners, and the program. However, in most observed classroom practices, a strategy of "giving reward" engaged by the teachers was evident to be increasing students' motivation in learning. It shows that this strategy has raised students' enthusiasm in following the English lesson. The small gifts from the teachers have positively triggered in other students a desire to do task better.

The long term motivation is built upon teachers' engagement. The teachers played a pivotal role in engaging students in learning. The learners have depended so much on the teachers' performances. If the teachers encourage the students to experience active learning in the classroom activities, the students will enthusiastically follow the teachers' commands. If the teachers appear confident and engaging, the students will be confident about the teachers. Therefore, students' self-esteem and self-confidence emerge as the result of their enthusiasm. If their self-esteem and self-confidence are blossoming then the intrinsic motivation will grow as well (Deci \& Ryan, 2011). If the motivation is embedded in learners, the success in learning is just a step ahead.

Teachers' beliefs about teaching are instrumental in shaping how they interpret what occur in their classrooms. Their experiences in teaching have formed capabilities in decision making, particularly in deciding which best practice should be applied for increasing students' motivation in learning English. However, there is no guarantee that experience alone can overcome the motivation problem in learning. As teachers and learners in rural areas seem to face complex drawbacks in establishing good learning environment caused by their socio-cultural background, there are big challenges in these areas. It is acknowledged that the teachers' prior education and enthusiasm are significant factors in teaching and learning process, particularly in choosing the best strategy how to motivate passive students. Given that motivation plays 
a pivotal role in language learning, the teachers consider important to motivate the unmotivated students.

\section{CONCLUSION}

This article has explained the issues, challenges and the motivational strategies engaged by the teachers of English in Madrasah Tsanawiyah in the three districts under study including the district of Bondowoso, Probolinggo, and Pamekasan. The research finding shows that the teachers had implemented various strategies for motivating students to learn English. The teachers showed the ability to employ motivational strategies such as giving reward, giving positive feedback, and maintaining students' learning confidence. Because the success of language learning has been credited according to students' levels of motivation, the teachers could embed the value of the importance of learning English by engaging fun and authentic activities in their classroom practice. As such, their students will be more self-motivated learners.

\section{REFERENCES}

Bauer, M. W., \& Gaskell, G. (2006). Qualitative Researching with Text, Image and Sound. London: Sage Publication.

Bogdan, R. C., \& Biklen, S. K. (2007). Qualitative Research for Education: An Introduction to Theory and Methods. Boston: Allyn and Bacon.

Chase, S. E. (2005). Narrative Inquiry: Multiple lenses, approaches, voices. In N. K. Denzin \& Y. S. Lincoln (Eds.), The Sage Handbook of Qualitative Research (3rd ed.). Thousand Oaks: Sage Publications, Inc.

Clandinin, D. J., \& Connelly, F. M. (2000). Narrative Inquiry: Experience and Story in Qualitative Research. San Francisco, CA: Jossey-Bass.

Creswell, J. W. (2012). Educational Research: Planning, Conducting, and Evaluating Quantitative and Qualitative Research (4th ed.). New Jersey: Pearson-Merill Prentice Hall.

Deci, E. L., \& Ryan, R. M. (1985). Intrinsic motivation and selfdetermination in human behavior. New York: Plenum. 
Deci, E. L., \& Ryan, R. M. (2011). Self-Determination Theory. In P. A. M. Van Lange \& A. W. Kruglanski (Eds.), Handbook of Theories of Social Psychology: Collection (Vol. 1-2, pp. 416437). London: Sage.

Denzin, N. K., \& Lincoln, Y. S. (2011). Handbook of Qualitative Research Design (4th ed.). London: Sage Publication, Inc.

Dornyei, Z. (2001a). Motivational Strategies in the Language Classroom. Cambridge: Cambridge University Press.

Dornyei, Z. (2001b). New Themes and Approaches in Second Language Motivation Research. Annual Review of Applied Linguistics, 21, 43-59.

Dornyei, Z. (2014). Motivation in Second Language Learning (pp. 518-531). London: zoltandornyei.co.uk.

Gardner, R. C., \& Lambert, W. E. (1959). Motivational variables in second language acquisition. Canadian Journal of Psychology, 13(4).

Machfudi, M. I. (2013). Language and Literature Teaching. Jember: STAIN Jember Press.

Renandya, W. A. (2014). Effective Strategies for Motivating L2 Learners. [Paper presented at the KAPEE International Conference Chuncheon National University of Education]. Chuncheon, South Korea.

Roberts, E. (2012). The Difference Between Self-Esteem and SelfConfidence. Healty Place, Americas's Mental Health Channel. Retrieved from http://www.healthyplace.com/ blogs/buildingselfesteem/2012

Ryan, R. M., \& Deci, E. L. (2000). Intrinsic and Extrinsic Motivation: Classic Definitions and New Direction. Contemporary Educational Psychology, 25, 54-67. doi:10.1006/ceps. 1999.1020

Ushioda, E. (2010). Motivation and SLA: Bridging the GapEUROSLA (pp. 5-20): John Benjamins Publishing Company. doi:10.1075/eurosla.10.03ush

Ushioda, E. (2011). Why autonomy? Insights from motivation theory and research. Innovation in Language Learning and Teaching, 5(2), 221-232. 